\title{
Transatlantica
}

Revue d'études américaines. American Studies Journal

\section{Direct Democracy on Election Day: Ballot Measures as Measures of American Democracy}

Donna Kesselman

\section{(2) OpenEdition}

Journals

Édition électronique

URL : http://journals.openedition.org/transatlantica/5279

DOI : $10.4000 /$ transatlantica. 5279

ISSN : 1765-2766

Éditeur

AFEA

Référence électronique

Donna Kesselman, « Direct Democracy on Election Day: Ballot Measures as Measures of American Democracy », Transatlantica [En ligne], 1 | 2011, mis en ligne le 04 janvier 2012, consulté le 29 avril 2021. URL : http://journals.openedition.org/transatlantica/5279; DOI : https://doi.org/10.4000/ transatlantica. 5279

Ce document a été généré automatiquement le 29 avril 2021.

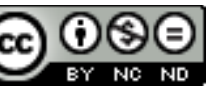

Transatlantica - Revue d'études américaines est mis à disposition selon les termes de la licence Creative Commons Attribution - Pas d'Utilisation Commerciale - Pas de Modification 4.0 International. 


\title{
Direct Democracy on Election Day: Ballot Measures as Measures of American Democracy
}

\author{
Donna Kesselman
}

1 Election 2008 has been meat for pundits and social scientists revisiting so much common political wisdom. One previously assumed given is the American electorate's presumed lack of "civic engagement", notably low Election Day turnouts. Did the highest participation rate in a century denote renewed commitment to the nation's governing institutions and leadership? One area of vibrant activism though, prior to the 2008 groundswell and since, has received less attention, that of direct democracy. Measures placed on ballots and hotly contested in two thirds of American states point to the changing nature of citizen participation in elections, if not a "remaking of social and political life". (Zukin, Keeter et al., 2002) The phenomenon is also related to generational change: at least until its decisive role in the 2008 presidentials, youth has moved away from traditional forms of representative democracy. (Mutz, 2006) Recourse to plebiscitary devices has had contradictory repercussions upon electoral processes: traditional mandates of officials and parties have been challenged, while direct democracy's newfound legitimacy have drawn citizens back to the polls. (Skocpol, Fiorina, 1999)

2 A closer look at local slates and stakes reveals underlying trends in American civilization and political stratagems which are hardly perceptible when viewed through the sole, media-focused yet necessarily distorted prism of presidential elections.

\section{Wedge Issues, Democracy and What Not}

3 Among the measures most energizing state voters, this dossier proposes three in-depth studies: immigration reform, same-sex marriage and "ethno-racial statistics". Due to their controversial nature they may be instrumentalized as electoral tactics, aimed at splitting apart or creating a "wedge" in an adversary's support base. 
Mario Menendez explores local plebiscitary drives in light of longer term evolutions of immigration rights. State-level ballot initiatives concerned with-generally attempting to stigmatize-immigrants have placed pressure upon federal legislators and policy formulation, subtly interacting with national security. Liberals have also used them to their own tactical ends, such as bringing Latino voters back to the Democratic fold: their defection in 2004 had been a factor in turning the tide. Exploiting bitterness of the Bush administration's infamous ICE (Immigration and Customs Enforcement) raids, which rounded up and deported immigrant workers and families, then helped divide Republicans: some legislators backed the president's immigration reform, others opposed it. The quandary was detrimental to 2008 Republican presidential candidate John McCain, from the Mexican border state of Arizona.

Guillaume Marche gives insight into the complex societal underpinnings of same-sex marriage, appearing on state ballots since 2004. Republicans positioned gay marriage to serve multiple political aims. The quintessential wedge splintered conservative religious Democratic constituencies, such as Hispanic Catholics and the working class (Miller, 2008), while functioning as a GOTV-get out the vote-tactic to mobilize the conservative Republican base. George W. Bush's pledge to support a constitutional ban is widely accredited with pushing him over the top in swing states such as Ohio. Based on ground research in Colorado, Marche proposes a campaign-based political interpretation as an alternative to the reductionist narrative of gay marriage poised uniquely in the terms of sex, religion and morality. His comparison with another wedge measure placed on the Colorado 2006 mid-term ballot but by liberals, one calling for an increase in the minimum wage, illustrates the interaction between social and economic issues in American politics.

6 In his study of "ethno-racial" statistics, whose legality and legitimacy California voters decided in Proposition 54 (2003), Olivier Richomme brings out the stakes around this so-called identity politics issue whose introduction in France has been suggested, notably with the aim of implementing policies of anti-discrimination, resulting, for the moment, in polemical debate. The piece explores the strengths and drawbacks of popular plebiscites as democratic forum of debate in the United States.

7 First, though, an introduction provides readers with basic definitions, facts and figures, including a ballot measures update and review of recent scholarship.

\section{Direct Democracy on Election Day: An Overview}

\section{A Progressive Era Legacy}

8 Concerned with the floundering state of American democracy, what they perceived as the ills of government and over-riding corporate-notably railroad and oil companyinfluence upon electoral politics, Progressive Era educators and reformers promoted the virtues of plebiscitary devices in the American states: the initiative, the referendum, the recall. By gathering a prescribed number of valid signatures of registered voters, issues raised on Election Day would harness the popular will and involve ordinary citizens in policymaking. ${ }^{1}$ A century later, direct lawmaking has experienced regained popularity. Since 1980 statewide ballot measures have numbered over 900, with thousands more at city and county levels. Measures, also called propositions, are umbrella terms. Today 38 states authorize at least some form of direct 
democracy, 24 states plus the District of Columbia allow for ballot "initiatives". The number of state-wide measures began shooting up in 2000, to reach a record 204 in 2006. The drop in 2008 (153 measures) follows the usual pattern in presidential election years while also raising expectations for a return to mainstream electoralism, riding on Obama coat-tails. The number did rise in some states in 2008, like Colorado. The total climbed to 184 in 38 states $^{2}$ in the 2010 midterm year, with a notable decrease in the specific category of citizen legislative initiatives. The 2010 approval rate of $64 \%$ was in between $60 \%$ in 2008 and $67 \%$ rate in 2004 and 2006: overall "yes" votes are consistently more frequent than "no" votes. Of the forty-two initiatives on the ballot-new laws placed on the ballot by citizen petitions-43\% were approved (the average approval rate for new-law initiatives is $41 \%)$. Of the 113 propositions placed on the ballot by legislatures, $73 \%$ were approved: as usual, voters were almost twice as likely to approve legislative measures than citizen petitions.

Ballot questions have been certified for spots on 8 statewide ballots in 2011 (as of August 25). Historically, odd-numbered election years feature significantly fewer measures than even-numbered years. Since 1970 odd-numbered years have had an average of 46. In 2009, voters cast their ballots on a grand total of 32 questions, a comparable figure, for the moment, to 2011. (For electoral statistics, see: Initiative \& Referendum Institute, Ballotpedia, National Conference of State Legislatures, Waters 2003, The Initiative and Referendum Almanac.)

10 Among the various forms of citizen lawmaking, ballot initiatives, whereby petitioners place a piece of legislation (statute law) or constitutional amendment before an electorate, are most common. ${ }^{3}$ They may be direct legislation initiatives, which are immediately binding, or indirect: imposed by voters for consideration on state legislature or municipal council agendas. The other common device, popular referendums, is the process by which voters can overturn disputed legislation (or a section of a law) enacted by a governing body. The denomination "popular" distinguishes them from the traditional procedure of referendum, which seeks public approval but originates in state legislatures, introduced by an elected official or appointed constitutional revision commission, though the media often confuses the two. Circulation periods, the time allotted to petitioners to obtain the minimum amount of required signatures, vary from 60 days in Massachusetts to four years in Florida or no time limits at all, as in Arkansas, Ohio or Utah. There has been no correlation established between the length of the circulation period and the amount of petitions that ultimately appear on the ballot, but very few petitions make it to Election Day.

11 Completing the tripartite mechanisms of direct democracy is the recall: the procedure by which voters can remove an elected official from office. While rarely used, one case is worth noting: in October 2003 California voters recalled California's Democratic governor Gray Davis and replaced him with Republican actor-businessman turned politician, Arnold Schwarzenegger. ${ }^{4}$ The year 2011 has seen recall elections emerge as a fateful arena of political standoff. Activists began circulating recall petitions for Republican senators in the days following Wisconsin Gov. Scott Walker's (R) bill's to strip collective bargaining rights of most public employee unions, which spurred state Capitol occupation and protests in February and March, reminiscent of Vietnam Warera fury. Among the nine subsequent recalls were five Republicans having voted for Walker's bill and some of the 14 Democratic Senators who had fled the state in 
February in opposition to this curb on labor rights. Ultimately, Democrats picked up two seats but were unable to wrest majority Senate control away from the GOP, which now holds a narrow 17-16 majority, previously a 19-14 edge. The nine recall elections in Wisconsin this year were the largest ever in the nation's history. Previously, in nearly 100 years there had been only 20 recall attempts, 13 successful. Collectively, more than $\$ 31$ million was spent on the recalls, largely from outside conservative groups, unions and others. The Democratic Party is pushing ahead with its plans to recall Walker next year.

12 Direct democracy provides grassroots perspective on evolutions in American society, shades of nuance to what is considered its ideological war-mongering, gauged by conservative and liberal hues. While electorally pertinent, these distinctions should not to be overstated given that fundamental political values-free market, individual rights, the role of the state-are more commonly shared in the United States than in other Western nations (Lowi, Ginsberg, Shepsle, 2008, 252). The dichotomy is arguably more significant than systematic partisan reference to the two mainstream parties, though no set of coherent philosophical principles defines or unites either group. Among other significant causal factors of public opinion are local political environments, which ballot measures help to produce.

Citizen lawmaking is a privileged tool for grasping the American political psyche-how individual attitudes and behaviors interact with politics-and the reflexive tactical adaptations by parties and interests groups. Observers gain more acute perceptions than the American public's portrayal as "polarized" into two kinds of states-red conservative Republican or blue liberal Democrat-, following suit of presidential electoral votes... thereby relativisingcatchy, media-hype/sound-bite characterizations, all the more so when they are semi-official and self-serving, as G.W. Bush's confident Karl Rove's year 2000 prediction of a "permanent Republican majority" or what would be fleeting reference to an Obama realignment. Direct democracy is a gauge of both impetuous outrage and incremental change in American public opinion.

\section{Ballot Measures and Trends: 2008-2011}

Ballot measures have been battlegrounds of choice for America's alleged culture wars; notably for conservative intent on mobilizing "moral voters". Thus, in 2008, Arkansas rebuffed adoption by gay partners; the wording goes even further to apply to any unmarried couples. New anti-gay marriage bans were also voted in Arizona, California (by a slim 52 to $48 \%$ margin) and Florida (by a whopping 62 to 38\%). By November 2008, 41 states $^{5}$ had passed "Defense of Marriage" Acts-DOMAs-or constitutional Amendments, most of which define marriage as a union of one man and one woman.

On a more progressive note, all three November 2008 election-day measures aimed at restricting abortion rights went down in defeat. California voters snubbed a constitutional amendment requiring physicians to notify parents or legal guardians of abortions involving a minor. An all-out ban with great ideological implications went down three to one in Colorado (73\% against): the state constitution would have defined human life from "the moment of fertilization". A second attempt was pushed back in 2010 by a larger margin (79\%). ${ }^{6}$ In 2008 South Dakota defeated an amendment to constitutionally ban abortions, excluding those performed in the extreme circumstances of rape, incest, a woman's health, also charging doctors performing 
abortions with criminal penalties (prison and fine). This attempt followed more stringently worded pro-life measures in the previous two legislative sessions, but which had been rejected by voters in this albeit conservative heartland state. Similar antiabortion efforts that year in Montana and Missouri did not collect enough signatures to qualify for the ballot. A 2010 measure passed in Alaska, though quite moderate: it forbids minors from getting an abortion without a doctor informing at least one parent before moving forward with the procedure. This weathervane will test the social conservative winds once again in a 2011 Mississippi measure which would "Define[s] human personhood as beginning at the moment of fertilization".

Following a decade of pro-life advances at both local and federal levels (Merchant, 2008), the defeat of several test cases, alongside Obama's two liberally-leaning Supreme Court nominations may jeopardize, or at least force their sponsors to reorganize, their planned Supreme Court showdown over the doctrine of privacy rights and a Roe $v$. Wade-abortions rights reversal. ${ }^{7}$ Such electoral setbacks also illustrate the gap which separates a conservative Republican Party apparatus, under pressure from an increasingly vocal and organized far-right, and small-town America's shift to more middle ground on social issues like abortion. A parallel observation may be made about Democrats: despite the party leadership's staunchly liberal stance, Democrat voters do not unanimously support abortion under all circumstances, Catholic Hispanics being a case in point (Pew Research Center, August 2006). The forms and grounds of public opinion change with the times, and even cultural wars must be carefully framed within their particular political and also polemical environments (Lakoff, 2004).

Anti-immigrant offensives were pushed back in the two states where they were run in 2008. California massively voted down the so-called Safe Neighborhoods Act: opponents denounced its "gang related and drug crime" frame as euphemism for minority and immigrant youth baiting. And yet, as explained below by Menendez, previous measures had successfully solicited California voters to curtail undocumented immigrant rights, such as access to public services. Even Arizona, despite its history of anti-immigrant ballot measures, rejected tighter sanctions in 2008 for undocumented workers as well as employers knowingly hiring them, procedures which incite discrimination against immigrants generally. Retrospectively, the proposed measure and zealous campaigning were harbingers of the current, national attention-drawing immigrant bashing in this state.

18 Though constitutionally Congress enjoys the power of the purse, initiatives give voters a direct say in state-level spending. Money matters-and it has taken on new dimensions since the September 2008 financial meltdown. Even in this crisis-ridden context, two thirds of government expenditure mandates were approved that year, including fifteen statewide government bond issues for programs costing over \$13 billion. Despite the state's ongoing budget crisis, California voters approved high-speed rail transportation to link its coastal and inland cities and construction of children's hospitals. Montana voted higher taxes to support state Universities while North Dakota and Massachusetts refused to lower personal and/or corporate income tax rates, entailing public service cutbacks. In 2010, 19 of 21 state bond issues were voted in nine states, including libraries and educational buildings in Alaska, water projects and dental care in Maine and pre-K (Kindergarten) education in New Mexico. Since the stock-market crisis, entailing bank bailouts and emergency recovery spending, state constitutional balanced budget amendments may dampen such mega-projects. What 
stand out nevertheless are these outright plebiscites for public infrastructure and services-counter-intuitive to the widely portrayed anti-government, free-market image of Americans.

Direct democracy impacts America's system of multilevel, interactive checks and balances government. For instance, voters approved California's Proposition 11 in 2008: congressional district boundaries will subsequently be drawn by an independent citizen redistricting commission, following existing procedures in Indiana. A ballot issue proposing to repeal the measure went down in defeat in 2010 (59.5\%) while another measure, named the "Voters First Act", gave the citizen commission specific mandate by setting out criteria for drawing-up districts. ${ }^{8}$ Legislative and congressional redistricting take place in every state in the wake of the federal census every ten years, the last one being in 2010. Measures about redistricting were on ballots that year not just in California, but also Florida and Oklahoma. Florida's constitutional amendments 5 and 6 were approved to ensure that legislative district boundary-drawing establish "fairness," are "as equal in population as feasible" and use "city, county and geographical boundaries". Oklahoma State Question 748 reformed, by enlarging membership of, the previously instituted commission.

These claims to more responsive, representative institutions are popular repudiations of the bi-partisan-though ethically questionable-practice of "partisan gerrymandering", whereby state legislative majorities turn to their own political advantage their power to reapportion congressional districts (Lowi, Ginsberg, Shepsle, 2008). The California, Florida and Oklahoma votes are worthy of Progressive Era expectations, as are term limits imposed by voters upon elected officials in twenty state legislatures since the early 1990s; six were subsequently overturned or declared unconstitutional by courts. Thus, while citizen lawmaking may check the work of legislators, the "people" do not necessarily have the last word: statute laws, even when introduced through popular initiative, must face judicial review under state and federal constitutions.

21 Gay marriage illustrates the complex intermingling of direct democracy, federalism, and institutional checks \& balances. California's 2008 constitutional amendment, which exclusively defines marriage as between one man and one woman, trumped the state Supreme Court's previous May 2008 ruling which had confirmed the legality of a San Francisco city ordinance on same-sex marriage. ${ }^{9}$ Gay-rights lawsuits then challenged Proposition 8, also in view of upholding the legal status of thousands of couples having married during the five-month interim. A California state Supreme Court decision subsequently upheld the voter-approved constitutional ban, but it was then challenged in federal court (Perry v. Schwarzenegger, 3:09-cv-02292). In August 2010 the federal District Court judge ruled that California's ban by state constitutional amendment on same-sex marriage was an unconstitutional violation of civil rights by national standards and that marriages could resume on August 18, 2010. But the United States Ninth Circuit Court of Appeals then stayed the ruling pending appeal, where the lower decision was then appealed once year later (as this article goes to press, decision still pending).

22 The stage is being set for a landmark Supreme Court constitutional interpretation. Article IV, Section 1's "Full Faith and Credit" clause clearly dictates that each state must honor the public acts, records and judicial proceedings of other states, such as marriages or drivers' licenses. Thus a contradiction lies in the coexistence today 
between a majority of state DOMAs and legal recognition in five states-four in the northeast: Connecticut, Massachusetts, Vermont, New Hampshire and most recently in New York in July 2011, henceforth the largest state where gay and lesbian couples can wed, giving the national gay-rights movement new momentum-plus Iowa, Washington D.C. and the Coquille Indian Tribe in Oregon. In these cases, legalization was introduced through legislation and court ruling. Eleven states have created legal unions that, while not called marriages, offer varying subsets of corresponding rights and responsibilities under local jurisdictions. ${ }^{10}$ Legislation recognizing same-sex marriage in Maine was subsequently overturned by ballot measure in 2009; in all 31 states where the issue has been put directly to a popular vote, the result has been bans. Congress itself complicated matters in 1996 when the Defense of Marriage Act declared that states are not obliged to recognize same-sex marriages, even if legal in another state.

$21^{\text {st }}$ century direct democracy may ultimately materialize the progressive strategy of constructing national social rights from the bottom, state-level up. Thus after successful 2006 mid-terms ballot measures more than half the states had introduced minimum wage hikes above the national rate, which had not been raised in a decade. This nationally coordinated liberal wedge issue campaign and its momentum-ten of the 17 tightest races had minimum wage initiatives on the ballot-helped usher in the $110^{\text {th }}$ Congress Democratic majority and its clear mandate for national minimum wage increase, which was voted in 2007. Likewise, local support gathered for stem-cell research ballot initiatives has built momentum towards legalization through federal legislation. ${ }^{11}$ It was a factor in candidate Obama's campaign promise and then partial satisfaction, when the president approved federal funding in a March 2009 executive order, thereby undoing his predecessor's 2001 prohibition.

In all cases, the stakes are high: in addition to their own emotional power and, notably, social conservatives' legendary organizational skills (Huret, 2008), ballot measures are embraced by lobbies and broad-based associative networks, entailing big-dollar financing (Deysine, 2006).

\section{Democratic or Not?}

Aspirations for direct popular input into public affairs challenge the philosophical virtues of representative democracy. The "people"-as collective voice and agency-, is displaced by alternative forums of debate and participatory governance, including individualized technology outlets like internet voting. Proponents, non-governmental organizations in particular, also acclaim direct democracy as an action-forcer: means of pressuring legislators to take action on controversial issues. Scholars have acknowledged its ability to increase the population's "social capital". Some have made clarion calls to replace the structures of western representative democracy, "to substitute the simplicity of majority rule by referendum for what must seem to many frustrated Americans the arcane, ineffective, out-of-date model of the Constitution" (Smith and Tolbert, 2007, 146-47).

There are detractors of course, though less vocal. First there is the classical denunciation of the referendum process: coined in such a way as to elicit the desired response, the advantage inevitably goes to he who asks the question. One current example in the U.S. concerns so-called civil rights initiatives. They typically assert that state institutions "shall not discriminate against, or grant preferential treatment to, 
any individual or group on the basis of race, sex, color, ethnicity, or national origin in the operation of public employment, public education, or public contracting" (see successful 2006 Michigan Civil Rights Initiative, MCFI: Amercian Civil Rights Institute, 2009). The implied notion of "equal treatment" appeals to equality-conscious citizens, notably minorities. But idealized wording of colorblind institutions has a history of masking de facto discrimination in the United States. Such was the case when California (1996) and Washington (1998) civil rights initiatives resulted in removal of affirmative action measures, ultimately decreasing minority student populations attending professional-law, medicine-degree programs. The Michigan MCFI was challenged in federal courts for violating the 1965 Voting Rights Act by deceptively misappropriating the term "civil rights". Sponsors were charged with systematic voter fraud for soliciting petition signatures with claims that a yes-vote would favor affirmative action or using questions such as "Do you oppose racism?" Certainly, despite projections by the initiatives' major promoter, conservative activist and American Civil Rights Institute president Ward Connerly, there was no "Super Tuesday for Equal Rights" in 2008: while passing in Nebraska, Colorado's civil rights initiative was defeated, and others did not make the ballot in Arizona, Missouri, and Oklahoma. In any event, courts have acknowledged their constitutionality and affirmative action has been weakened by these effective bans on race and gender-based preferential treatment as well as their ideologically charged campaigns. In a 2010 comeback, the measure passed by $59 \%$ in Arizona: proposed within the anti-immigration furor surrounding a state law, it has helped to fuel already flaming local political moods.

However forthright the endeavor, the democratic content of direct consultation is questionable; notably when complex issues are inevitably framed in simplistic fashion. Are voters qualified to evaluate the long-term repercussions of policies? (Zimmerman, 1986) California, the most populous state and direct democracy locomotive is once again a case in point: 2008's Proposition 7 called for clean energy and utilities to generate $20 \%$ of electric power from renewable energy by 2010 . Interviews carried out during the month preceding the November election ${ }^{12}$ illustrate how even voters most likely to grasp the stakes, including those who read about issues, are educated in technical fields or committed to environmental issues, found it hard to make up their minds. Difficulties compounded when facts and cogent argumentation gave way to suggestion and speculation due to programmed dis- and over-information. Both proponents and opponents of Proposition 7 portrayed themselves as avid environmentalists. "Yes vote" ads quoted Nobel-Prize winning scientists advocating alternative energy sources... Opponents denounced Proposition 7 as a "costly, flawed, poorly written energy scheme" (leaflet in possession of author). Prop 7 failed.

Also problematical for democracy is the point to which ballot measures, like candidate elections, have become high-profile communication jamborees-3.4 million dollars in partisan videos for Proposition 7 alone. In 2010, a total of $\$ 379$ million was spent, according to December 2010 campaign finance reports. Statewide contributions ranged from Iowa's $\$ 41,250$ to California's $\$ 217,342,328$. Then there is the billion-dollar petition-drive market. Far from the romantic image of street-corner activists hailing down concerned citizens to promote a worthy cause, the bustling business collects signatures for a fee.

In view of California elections 2011, the distribution giant Amazon pumped millions into paying signature collection for a referendum to voters and advertising to ward off 
budget measures requiring sales tax for on-line retailers. State Sen. Loni Hancock, DBerkeley, objected: "The initiative and referendum process has increasingly been hijacked by large corporations for measures that would benefit their companies and business." The mere threat already impacted the legislative process, for the state budget bill was subsequently amended and weakened this particular taxing prerogative (San Francisco Chronicle, August 26, 2011).

This brings us full circle. Charges of undue dominance of corporate interests are being echoed once again, one century later, but this time aimed at ballot measures themselves. For progressives, sky-rocketing price tags favor elites and their ability to impact electoral outcome, if not simply to buy legislation at the ballot box (Boehmke, 2005; Smith, Tolbert, 2007). Empirical research, however, does not conclusively support such accusations of undue corporate dominance over labor and other popular interests. Passage rates are actually low in so-called David $v$. Goliath contests, where citizen groups are outspent: corporate interests are not necessarily successful in getting their views to prevail. Likewise, disproportionate funding can often be traced to lack of meaningful support generated by citizen group campaigns (McConville, 2006, 277-79).

One must not lose sight of the opportunity costs incurred by these privately financed mega-operations. Labor organizations, for instance, gain at best pyrrhic victories when valuable resources are diverted. Such was the case for the "Paycheck Protection" schemes placed on ballots since the 1990s: the AFL-CIO succeeded in pushing back these attempts to restrict labor union participation in political campaigns, but at a hefty cost to organizing war chests (Kesselman, 1999). Another anti-labor statute initiative in 2001 turned Wyoming into a Right-to-Work State, further limiting already restrictive federal labor laws on unionization. It was one of the most costly ballot campaigns in history and thus an outright defeat for labor. In addition to the specific question at hand, the longer-term impact of weakening Labor's finances explicitly counts among its adversaries' multiple political aims.

In addition to ideological scorn-"mob rule", the tyranny of the majority-many legislators have criticized direct democracy based upon precedent: plebiscitary lawmaking impinges state congresses' prerogatives in passing future laws. California's path-breaking Proposition 13 capped property taxes in 1978 and triggered off the modern initiative wave: it has been subsequently blamed for declining public services, notably California's once exemplary educational system (Schrag, 1998). The ambiguous nature of direct democracy as countervailing power also lies in its difficulties to establish the veritable will of the people. A 2002 National Conference of State Legislatures concludes that states without the initiative process should not consider adopting it and that:

the initiative has evolved from its early days as a grassroots tool to enhance representative democracy into a tool that is too often exploited by special interests. The initiative lacks critical elements of the legislative process and can have both intended and unintended effects on the ability of the representative democratic process to comprehensively develop policies and priorities. (NCSL 2002, I\&R Task Force on the current state of the initiative process, quoted in Boehm, 2005, 10)

Public support of the initiative process nevertheless remains high. According to surveys, citizens in initiative states believe themselves to be competent to decide ballot questions and likewise consider the publicly-initiated lawmaking to be no less problematic or corrupted than the legislative process (Boehm, 2005). 


\section{Scholarship on Ballot Measures}

Recent scholarship has focused on the indirect effects of populist mechanisms. What are the "spillover effects" of issues and campaigns upon participation and voting behavior? (Magelby, 1984) Emotionally charged issues dealing with family values and fundamental rights have mobilized voters, in this nation known for high abstention rates, and influenced electoral outcomes. Playing the "race card" in ballot measures that stigmatize illegal immigrants induced many voters, even Independent and Democratic, to elect a Republican governor in California in 1994 (see Menendez below). of course, establishing specific causal relationships is complex. Contrary to widely held assumptions, gay-marriage measures on 2004 ballots may not have been the factor of Bush's decisive taking of Ohio. It has been argued that participation that year rose proportionally in every state, even where gay marriage was not on the ballot (Abramowitz, 2004).

As they spill over onto broader electoral agendas, ballot measures impact voter decisions in other races. Political scientists have set out the factors affecting candidate choices: personal characteristics (including incumbency, character, name recognition-e.g. Schwarzenegger); program but especially single issues; party loyalty. A recent hypothesis posits how ballot measures elevate certain issues to the point of establishing a set of voting criteria: they spillover to voter judgments with regards to a candidate's association with these particular issues (Nicholson, 2005). Following the correlating "visibility hypothesis", ballots have the greatest impact at midterm, without the centralizing effect of the presidential contest, and in "down ballot" races like Congress or state offices. Subsequently, the alleged existence of Democratic or Republican party "mindsets"-tending to fuse all levels of party politics-is over-stated, particularly in direct-democracy states enjoying vibrant electoral environments of their own (Nicholson, 2005).

Scholars of secondary or indirect levels of political processes have recast the debate: it traditionally opposes direct versus representative paradigms in terms of their respective democratic contents. Thus, plebiscites have had positive indirect effects upon turnout (midterm and presidential elections) and confidence in government, enhancing political knowledge as well. This is consistent with democratic Progressive Era norms, as with civic engagement studies notions of a voting population's social capital (Putnam, 2000; Skocpol, Fiorina, 1999). What's more, political parties in initiative states are more energized while membership is higher in citizen and not-for-profit interests groups (Smith, Tolbert, 2007). Such groups are more involved in "outside" or membership-intensive tactics, like organized protests and electioneering, giving preference to shaping public opinion and expanding their roots in longer-term constituencies (Boehmke, 2005).

Ballot access and campaigns contribute to the restructuring of politics and popular pressure. It is a complex phenomenon, which arguably derails representative institutions when circumventing legislatures, while tending to strengthen American democratic life. 


\section{Telltale Signs and Political Testing Grounds?} United States and state legislation under federalism, that of marijuana. ${ }^{13}$ While federal law outlaws all cannabis use and numerous states continue to inflict criminal charges, marijuana initiatives in states, counties or cities, since the 1970s, are aimed at liberalizing or in some way decriminalizing its use, possession, and/or sale. Use is already decriminalized ${ }^{14}$ in Massachusetts (2008), Colorado, Michigan and more surprisingly in Utah (2000)-but supporters outspent opponents in this state 40 to 1. Similar measures were rejected, however, in South Dakota, Oregon, Alaska, Nevada, Ohio. An initiative in 2008 did not receive enough signatures in Washington State. Marijuana is decriminalized by law in California, where almost all legal penalties have been removed. Yet on November 2, 2010, California's high profile Proposition 19 was defeated, and thus its outward legalization for personal cultivation, possession and transportation. For University of Southern California's Initiative \& Referendum Institute, while favoring legalization in principle, voters disapproved of some applications such as local in lieu of state regulatory frameworks and the authorization of workplace use, with the burden of proof of "actually impairing" job performance placed upon employers. Support for medical use of marijuana, though, has grown slowly but surely, voted in over a dozen states. It was approved by voters in 2010 in Arizona but voted down in South Dakota. ${ }^{15}$ A defeated 2010 Oregon measure continues to allow medical use but thus did not take the next step to further institutionalize its regulation by licensing farmers and authorizing research in state agencies to develop quality control standards. Ground research carried out among low-wage populations in California in 2011 indicate that being authorized to obtain a "medical marijuana card" has become an objective for a portion of this population, with subsequent consequences in terms of individualization and de-politization.

The Arizona Proposition 107 Civil Rights initiative which, as we have seen, actually discriminates against minorities by eliminating affirmative action, fits into the current local maelstrom. Arizona's 2010 anti-immigrant law (SB 1070) has polarized American politics by attempting to limit immigrant rights in the name of states' rights. Supporters across the nation blame immigrants for many woes, like unemployment or drug-trafficking. Detractors denounce the law for opening the door to racial profiling: any individual may be questioned about their immigration status based upon the arbitrary criterion of "reasonable suspicion". The AFL-CIO labor federation has joined this condemnation saying that SB 1070 also targets workers' rights: an employer confronted with Latino workers' complaints, be they in the form of picket lines or lawsuit-could simply call on police to arrest the workers under the claim of reasonable suspicion (Labor Council for Latin American Advancement, 2010). Also criticized is the challenge to federal government prerogatives of immigration control as Arizona state public employees are henceforth granted enforcement powers. Immigration rights crystallize the raising of racism's ugly head in the U.S.A. today. 

coordinated to undermine national liberal agendas, and notably president Obama's. The "card check" system of unionization is a priority for U.S. Labor: it would facilitate the ability for workers to unionize by signing-up in lieu of the complex voting system many claim favors employer intimidation practices. It was endorsed by presidential candidate Barack Obama. In November 2010, Arizona, South Carolina, South Dakota and Utah passed constitutional amendments requiring secret elections for union elections. All four measures were sponsored by state legislatures and meant to circumvent attempts to encourage unionization through federal law. In another anti-worker move, Louisiana voters approved a constitutional amendment requiring a supermajority for the legislature to increase benefits for public worker retirement systems. A November 2011 ballot measure in Ohio attempts to quell Wisconsin's anti-union groundswell. During the recalls the Huffington Post wrote (10 August, 2011): the "stand by Wisconsin Republicans against a massive effort to oust them from power could reverberate across the country as the battle over union rights and the conservative revolution heads toward the 2012 presidential race". Ohio Issue 2 "would repeal a measure which limits collective bargaining for public employees in the state", introduced here in the wake of the Wisconsin governor's union-busting onslaught. public health plan, local measures have been introduced to bar this route. They prohibit any statute law or regulation requiring people to have health insurance or penalizing them for paying their health bills with their own money, thereby proclaiming an individual's "right to pay" for private insurance. Missouri voters approved such a measure during the 2010 August primary election by $71 \%$ : somewhat symbolic given, as is common in primaries, a very low turnout, but entering the institutional books nonetheless. The following November, voters in Arizona and Oklahoma followed suit, while Colorado voters rejected the measure. The "yes votes" are formally at odds with the key provision of the historical 2010 Affordable Health Care Act which would make it mandatory for citizens to procure health insurance or face fines by 2014 (White House, 2010). They served as political foundation for the incoming Republican majority $112^{\text {th }}$ Congressional vote to rescind the law (not followed in the Senate). A telling measure will be before voters in Ohio in November 2011: posterior to the 2010 law it would "exempt residents of ohio from national health care mandates." In light of such persistent state-level defiance a Supreme Court showdown might decide the ultimate fate of Obamacare.

The overall conservative-leaning 2010 ballot issues year may or may not have been "tea party-fueled", as the Initiative \& Referendum Institute claims (Ballotwatch, 2010). As we have attempted to show, factors at play in local political playing fields are complex, multiple and in constant evolution. More fundamentally, though, the resurgence of "states' rights" as vehicles for thwarting the acquisition of nationally attributed social rights harks back to less glorious eras of the American political legacy, be it in the name of denying citizenship to slaves or collective worker organization. Whatever the ideological tint, state-level political environments, especially through the use of direct democracy, are powerful tools for consensus-building. They are privileged vantage points for grasping the underlying dynamics of American politics and citizenship. 


\section{BIBLIOGRAPHIE}

ABRAMOWITZ, Alan, "Terrorism, Gay Marriage, and Incumbency: Explaining the Republican Victory in the 2004 Presidential Election", The Forum 2, n², 2004, www.bepress.com/forum.

Arizona Ballot Proposition Guide, 2008, http://www.azsos.gov/election/2008/Info.

BOEHMKE, Frederick J., The Indirect Effect of Direct Legislation: How Institutions Shape Interest Group Systems, Columbus, The Ohio State University Press, 2005.

BusinessWeek Online, "The Deepest Divide: God, Guns, And Gays. In the struggle for swing voters, 'values' issues are about to take center stage", 17 May 2004.

California Ballot Proposition Guide, 2008.

DEYSINE, Anne, Les États-Unis aujourd'hui : permanence et changements, Paris, La Documentation française, 2006.

HURET, Romain (ed.), Les conservateurs américains se mobilisent : L'autre culture contestataire, Paris, Editions Autrement, 2008.

KESSELMAN, Donna, "Financement des élections : mise en cause des syndicats américains", dans Anne Deysine, ed., Argent, Politique et Corruption, Nanterre, Éditions PUBLIDIX, 1999.

KEYSSAR, Alexander, The Right to Vote: The Contested History of Democracy in the United States, New York, Basic Books, 2000.

KEY, V.O. Jr. and Winston W. CROUCH, The Initiative and Referendum in California, Berkeley, CA, University of California Press, 1939.

LAKOFF, George, Don't Think of an Elephant: Know Your Values and Frame the Debate, White River Jct., Vermont, Chelsea Green Publishing, 2004.

LOWI, Theodore, GINSBERG Benjamin, SHEPSLE, Kenneth, American Government: Power and Purpose, Brief Tenth Edition, New York, W.W. Norton \& Company, 2008.

MAGLEBY, David, Direct Legislation: Voting on Ballot Propositions in the United States, Baltimore, John Hopkins University Press, 1984.

MCCONVILLE, Charles T., "Muzzling the Mouthless Speaker: The Reform Community's Prescription For Corporate Domination in State Issue Campaigns", Capital University Law Review 279, Fall 2006, 245.

MERCHANT, Jennifer, "Les militants prof-life à l'échelle locale”, dans Huret, ed., Les conservateurs, 2008, 142-254.

MILLER, Kenneth P., “The Democratic Coalition's Religious Divide: Why California Voters Supported Obama but Not Same-Sex Marriage", Revue Française d'Études Américaines, n¹19, 2008, 46-64.

MUTZ, Diana C., Hearing the Other Side: Deliberative versus Participatory Democracy, New York, Cambridge University Press, 2006.

NICHOLSON, Stephen P., Voting the Agenda: Candidates, Elections and Ballot Propositions, Princeton, Princeton University Press, 2005. 
Pew Research Center for the People and the Press, 3 August 2006, "Pragmatic Americans Liberal and Conservative on Social Issues: Most Want Middle Ground on Abortion", http://www.peoplepress.org/2006/08/03/pragmatic-americans-liberal-and-conservative-on-social-issues/2/.

PUTNAM, Robert, Bowling Alone, New York, Simon \& Schuster, 2000.

SMITH, Daniel A. et Caroline J., TOLBERT, Educated by Initiative: The Effects of Direct Democracy on Citizens and Political Organizations in the American States, Ann Arbor, The University of Michigan Press, 2007.

SKOCPOL, Theda et Morris P. FIORINA (eds.), Civic Engagement in American Democracy, New York, Russell Sage Foundation, 2009.

WATERS, M. Dane, The Initiative and Referendum Almanac: A Comprehensive Reference Guide to the Initiative and Referendum Process, Raleigh Durham, North Carolina, Caroline University Press, 2003.

White House 2010, www.whitehouse.gov/blog/2010/03/23/whats-health-care-bill.

ZUKIN, Cliff, KEETER, Scott, ANDOLINA, Molly, JENKINS, Krista, DELLI CARPINI, Michael X., A New Engagement? Political Participation, Civil Life, and the Changing American Citizen, College Park, Md., The Center for Information and Research on Civic Learning and Engagement, 2002.

\section{Websites (last consulted January 2011)}

American Federation of Labor-Congress of Industrial Organizations, www.afl-cio.org.

American Civil Rights Institute, http://www.acri.org/.

Ballotpedia, http://ballotpedia.org/.

Citizen and Democracy Project (the), www.citizendemocracy.net.

Initiative \& Referendum Institute, University of Southern California, www.iandrinstitute.org, notably: "Ballotwatch", "Initiative Use 1902-2008", “Are Ballot Propositions Spilling over onto Candidate Elections?", “Election 2008: Mixed Results", “Election 2010 Preview: Not About the Economy".

Council for Latin American Advancement 2010, AFL-CIO, www.lclaa.org/aflcio.org.html. National Conference of State Legislatures, http://www.ncsl.org/IssuesResearch/. Pride at Work, AFL-CIO, www.prideatwork.org.

\section{NOTES}

1. The modern U.S. system of initiative and referendum originated in the state of Oregon in 1902, when the Oregon Legislative Assembly adopted it by an overwhelming majority and ran its first initiative in 1904. The "Oregon System", as it was at first known, subsequently spread to many other states to become one of the signature reforms of the Progressive Era.

2. Alabama, Alaska, Arizona, Arkansas, California, Colorado, Florida, Georgia, Hawaii, Idaho, Illinois, Indiana, Iowa, Kansas, Louisiana, Maine, Maryland, Massachusetts, Michigan, Missouri, Montana, Nebraska, Nevada, New Jersey, New Mexico, North Carolina, North Dakota, Oklahoma, Oregon, Rhode Island, South Carolina, South Dakota, Tennessee, Utah, Vermont, Virginia, Washington, Wyoming.

3. The most active states with regards to ballot initiatives since they were introduced in 1904 are, in order, Oregon, California, Colorado, North Dakota, Arizona.

4. On October 7, 2003, Gray Davis was removed from office by $55.4 \%$ of the state electorate voting "Yes", in favor of a recall. The second question on the ballot, whose validity would hinge upon 
the result of the first, elected Schwarzenegger as his successor with $48.6 \%$, the clear frontrunner among 135 candidates. Though permitted under state law, in this exceptional instance no primary election was held to determine which candidates would represent the major parties. Previous California governors, including Pat Brown, Ronald Reagan, Jerry Brown, and Pete Wilson, had faced recall attempts, but which were unsuccessful.

5. State Constitutional amendment bans have been voted in 29 states: Alabama, Alaska, Arizona, Arkansas, California, Colorado, Florida, Georgia, Idaho, Kansas, Kentucky, Louisiana, Michigan, Mississippi, Missouri, Montana, Nebraska, Nevada, North Dakota, Ohio, Oklahoma, Oregon, South Carolina, South Dakota, Tennessee, Texas, Utah, Virginia and Wisconsin.

6. The 2010 Colorado Fetal Personhood, Amendment 62 read: "An amendment to the Colorado Constitution applying the term 'person' as used in those provisions of the Colorado Constitution relating to inalienable rights, equality of justice and due process of law, to every human being from the beginning of the biological development of that human being."

7. Roe v. Wade, 410 U.S. 113, was the 1973 landmark United States Supreme Court decision which legalized abortion. The Court held that the constitutional right to privacy extends to a woman's decision to have an abortion.

8. Proposition 20 imposed upon the commission to redraw congressional district boundaries, previously created by Proposition 11, the notion of "community of interest", defined as "a contiguous population which shares common social and economic interests that should be included within a single district for purposes of its effective and fair representation. Examples of such shared interests are those common to an urban area, an industrial area, or an agricultural area, and those common to areas in which the people share similar living standards, use the same transportation facilities, have similar work opportunities, or have access to the same media of communication relevant to the election process."

9. For a history of the Gay Marriage issue, especially in California preceding 2008, see Kenneth P. MILLER, 2008, "The Democratic Coalition's Religious Divide: Why California Voters Supported Obama but Not Same-Sex Marriage", Revue Française d'Études Américaines, n¹19, 46-62.

10. The 11 states are: California, Colorado, Hawaii, Maine, Maryland, Nevada, New Jersey, Oregon, Rhode Island, Wisconsin and Washington. Attempts to introduce same-sex marriage have not succeeded in New York; however in 2008 New York Governor David Paterson issued a directive requiring that all state agencies recognize same-sex marriages performed elsewhere.

11. A citizen-initiated initiative to amend the Missouri Constitution to ban stem-cell research did not appear on the 2010 state ballot for lack of qualifying signatures.

12. Random interviews of 43 eligible voters.

13. Marijuana initiatives pertain to the legal status of marijuana. They generally liberalize or in some way decriminalize its use, possession, and/or sale in a particular state. This may be restricted to medical prescription or personal use for adults, accompanied by counselling for minors.

14. Decriminalized cannabis may incur, depending on the local law, civil fines, drug education, or drug treatment in place of incarceration and/or criminal charges for possession of small amounts of cannabis. In other cases, various cannabis offenses have been made the lowest priority for law enforcement. Movements support efforts ranging from reducing penalties for cannabis-related offenses to removing all penalties related to cannabis, including sale and cultivation.

15. While cannabis for recreational use is illegal in most parts of the world, its use as a medicine is legal in a number of territories, including Canada, Austria, Germany, the Netherlands, Spain, Israel, Italy, Finland, and Portugal. 


\section{RÉSUMÉS}

Ballot Measures (or Propositions) are a form of Progressive Era direct democracy which has regained momentum in recent years. Re-energizing voters in the $38 \mathrm{U}$. S. states where they raise grassroots and often controversial "wedge issues", they also have spill-over effects in other areas of politics and civil engagement. This introduction provides background information about their workings and an update on recent stakes in local political environments: it introduces in-depth studies published in this issue of Transatlantica.

\section{INDEX}

Keywords : Ballot measures, ballot initiatives, direct democracy, elections, U.S. politics, liberalism, conservatism, federalism, Supreme Court.

\section{AUTEUR}

\section{DONNA KESSELMAN}

University Paris East Créteil 